\title{
Chemical composition, acetyl cholinesterase inhibitory properties and brine shrimp toxicity of essential oils from Ficus capensis Thunb from Nigeria
}

\author{
S. A. ABOABA * , I. A. OLADOSU and O. EKUNDAYO \\ Department of Chemistry, University of Ibadan, Ibadan, Nigeria. \\ *Corresponding author,E-mail: sa.aboaba@mail.ui.edu.ng, Tel: 2348038011394
}

\begin{abstract}
Essential oils were isolated from leaves, stem barks and root barks of Ficus capensis (Moraceae) by hydrodistillation and the chemical constituents identified by means of GC and GCMS. A total of thirty-seven compounds were characterized in the essential oils. The major constituents were $\alpha$-pinene, $\beta$-pinene, $\alpha$-cadinol and $n$-hexadecanoic acid. Toxicity to brine shrimp ranged between $16.38 \mu \mathrm{g} / \mathrm{mL}$ and $43.11 \mu \mathrm{g} / \mathrm{mL}$ while the three oils exhibited acetyl cholinesterase inhibitory activity in the range $11.22 \mu \mathrm{g} / \mathrm{mL}$ and $14.65 \mu \mathrm{g} / \mathrm{mL}$.

(C) 2010 International Formulae Group. All rights reserved.
\end{abstract}

Keywords: Ficus capensis, Moraceae, $n$-hexadecanoic acid, $\alpha$-cadinol, $\alpha$-pinene.

\section{INTRODUCTION}

The genus Ficus is a large one with about 1,000 species (Berg, 1989). Ficus capensis Thunb (Moraceae) is also known as Ficus sur Forssk. It is a tree of variable height (4-9 m). It has spherical crown, often lowbranched and widespread in tropical Africa and South Africa of variable species. The tree is believed to have fetish attributes in the promotion of stock and crop increases as it confers fertility (Irvine, 1961).

The volatile compounds of the fig of $F$. capensis growing in France were studied by Grison-Pige et al. (2002). The essential oil was found to contain twelve compounds. The predominant compounds were $(E)$ - $\beta$-ocimene $(40.8 \%)$, germacrene D $(15.4 \%)$ and $(E, E)-\alpha-$ farnesene $(11.4 \%)$.
The extract of $F$. capensis exhibited antimicrobial activity against Vibrio cholerae, a microbe that causes cholera (Akinside and Olukoya, 1995). In another related study, the aqueous extract of $F$. capensis and other plants were tested in-vitro against chloroquine (CQ)-sensitive and resistant strains of Plasmodium falciparum. The extract of $F$. capensis proved to be active $\left(\mathrm{IC}_{50}<100\right.$ $\mu \mathrm{g} / \mathrm{mL}$ ) (Muregi, 2003).

Other species of Ficus have also been the subject of literature discussion. The analysis of the volatile constituents of $F$. exasperata revealed the presence of thirteen compounds. The major compounds were 1,8 cineole (13.8\%), E-phytol (13.7\%), p-cymene (11.4\%), $\beta$-ionone (7.5\%), 6,10,14-trimethyl2-pentadecanone $(7.0 \%)$, cyclooctasulphur 
(6.3\%) and caryophyllene oxide (5.4\%) (Sonibare et al., 2006). The root bark of $F$. exasperata comprises of $\alpha$-terpineol (33.7\%), $\alpha$-pinene $(10.8 \%)$ and sabinene $(5.6 \%)$ as the prominent constituents (Oladosu et al., 2009).

The fig volatile compounds of twenty Ficus species were also analyzed and 99 different compounds were identified. These compounds were terpenoids, aliphatic compounds and products from the shikimic acid pathway (Grison-Pige et al., 2002). Proffit and Johnson (2009) compared the volatile organic compounds emitted by receptive syconia of $F$. sur Forssk and $F$. sycomorus.

Sharaf et al. (2002) reported clear differences in the flavonoid profiles of four Ficus species: $F$. altissima Blume, F. nitida Thunb, F. carica L. and F. pseudosycamonus Decne. F. altissima showed the presence of six methylated flavonoids while no methylated flavonoids were detected in the other three species. The presence of 12 different alkanes in the leaf waxes of some Ficus species was reported by Sonibare et al. (2005). Of the twelve alkanes that were identified, it was observed that hentricontane and tricontane occurred as major components in all the twenty four species investigated. Cytotoxic triterpenes have also been isolated from the aerial shoots of $F$. microcarpa (Chiang et al., 2005).

This study was aimed at characterizing the essential oil constituents of Ficus capenis and also to investigate the numerous biological activities through the different assays described below.

\section{MATERIALS AND METHODS \\ Plant material}

The plant was collected in Ibadan (Oyo State, Nigeria) around Sabo area in February 2004. The plant sample was identified and a voucher specimen deposited at the Herbarium of the Forestry Research Institute of Nigeria (FRIN), Oyo State (FHI 107415). Air dried samples were ground. Batches of $500 \mathrm{~g}$ plant materials were submitted to hydrodistillation for $3 \mathrm{~h}$ using a Clevenger-type apparatus. The resulting essential oil was kept refrigerated until it was analyzed.

\section{Gas chromatographic analyses}

Gas chromatographic analyses (GC) of the oils were performed on an Orion Analytical Micromat gas chromatography fitted with a thermal conductivity detector (TCD). The separation was achieved by capillary columns of different polarities, CPSil-5 (25 m x $0.25 \mathrm{~mm}$ i.d, $0.15 \mu \mathrm{m}$ film thickness), equivalent to OV 101, and CPSil19 (25 m x $0.25 \mathrm{~mm}$ i.d) similar to BP10.

The essential oils were diluted with $n$ hexane at a ratio of 1:5. The diluted oil (0.1 $\mu \mathrm{L})$ was injected into the GC. The column temperature was programmed from $50{ }^{\circ} \mathrm{C}$ to $230{ }^{\circ} \mathrm{C}$ at $3{ }^{\circ} \mathrm{C} / \mathrm{min}$. The injector and detector temperatures were maintained at $200{ }^{\circ} \mathrm{C}$ and $250{ }^{\circ} \mathrm{C}$ respectively. The carrier gas was hydrogen at a pressure of 0.5 bars and a flow rate of $120 \mathrm{~mL} / \mathrm{min}$.

Gas chromatography-Mass spectrometer (GC-MS) analyses of the essential oil samples were carried out on a HewlettPackard Gas Chromatography (GC) HP5890A, interfaced with a VG Analytical 70-250s double focusing mass spectrometer, operating at $70 \mathrm{eV}$, with an ion source temperature of $230{ }^{\circ} \mathrm{C}$. The $\mathrm{GC}$ was fitted with a $25 \mathrm{~m} \mathrm{x} 0.25 \mathrm{~mm}$ i.d fused silica capillary column coated with CPSil-5. Helium was used as the carrier gas at $120 \mathrm{~mL} / \mathrm{min}$. The GC operating parameters were identical with those of the GC analyses. The mass spectral data were acquired and processed by an on-line desktop computer.

The retention time of the different component from the GC analysis of the essential oils were converted to Kovat indices (KI) using Kovat formula. The mass spectra of each compound from the GC-MS analysis were compared with authentic compounds (Davies, 1960; Adams, 2001).

\section{Toxicological assay \\ Brine shrimp lethality test}

Sea water was collected from the ocean in Lagos, South West, Nigeria. The shrimps 
(Artemia salina) were purchased from Felimar Aquaculture Centre, Ijebu-ode, Ogun State (produced by Coppens International bv, Helmond, Holland). Sea water $(200 \mathrm{~mL})$ was added to the hatching chamber and shrimp eggs added. The hatching chamber was a plastic bowl, partitioned in to two compartments. The partition was perforated such that the nauplii could swim through to the other side after hatching. The eggs were allowed to hatch for $48 \mathrm{~h}$ and mature as nauplii at room temperature. The nauplii were then harvested with a pipette after attracting the organism to one side of the vessel with a light source.

The essential oils were prepared in sea water into vials at 1000,100 , and $10 \mu \mathrm{g} / \mathrm{mL}$ (each test in triplicate). The essential oils had been previously dissolved in $2 \mathrm{~mL}$ of Dimethylsulfoxide (DMSO) since they are not soluble in water and $0.5 \mathrm{~mL}$ each of the dose level was introduced in a test-tube to which 4 $\mathrm{mL}$ of sea water added. 10 shrimps per test tube were added to each concentration and made up to $5 \mathrm{ml}$ seawater to make 1000-10 $\mu \mathrm{g} / \mathrm{mL}$ of final concentration of extract. After $24 \mathrm{~h}$, the number of deaths over the number of total shrimps (survivors) was counted and recorded (McLaughlin et al., 1973).

The data were analyzed statistically using Finner Computer Programme to determine $\mathrm{LC}_{50}$ values. The control experiment was in place without the test solutions (Finney, 1971).

\section{Acetyl cholinesterase enzyme assay}

Fresh sheep liver was obtained from a healthy sheep just after being slaughtered. A $1 \%$ homogenate $\mathrm{w} / \mathrm{v}$ of the sheep liver was prepared in double distilled water at $0{ }^{\circ} \mathrm{C}$.

The acetyl cholinesterase (AChE) inhibitory properties of the test compounds were done by colorimetric method but with the following modifications (Baum, 1971). Three different concentrations $(5,10,20$ $\mu \mathrm{g} / 0.1 \mathrm{~mL}$ of propanone) of the essential oils were prepared separately in test tubes and the solvent propanone was allowed to evaporate.
$0.1 \mathrm{~mL}$ of the $1 \%$ sheep liver homogenate was pre-incubated with $5,10,20 \mu \mathrm{g}$ of the essential oils, separately for 15 minutes at 37 ${ }^{\circ} \mathrm{C}$ in a thermostatic water bath. A positive control Huperzine A was adopted. The Huperzine A technical grade (obtained from Sigma Co. U.S.A) was also pre-incubated in the same manner as described above with 0.1 $\mathrm{mL}$ of $1 \%(\mathrm{w} / \mathrm{v})$ homogenate at $5,10,20 \mu \mathrm{g}$ amounts to allow inhibition of liver cholinesterase by test compounds.

Immediately after pre-incubation, 0.2 $\mathrm{mL}$ of $0.2 \%$ fast blue $\mathrm{B}$ (a diazotized product of 4-benzoylamino-2,5-dimethoxy aniline$\mathrm{ZnCl}_{2}$ ) in water was added followed by 0.1 $\mathrm{mL}$ of $0.01 \mathrm{M}$ ethylacetoacetate substrate in acetone and the reaction mixture was again incubated for one minute for enzymatic reaction. The reaction mixture was made up to a total of $1.0 \mathrm{~mL}$ with distilled water prior to addition of substrate. The enzymatic incubation time was 1 minute after the addition of substrate. The enzyme activity was stopped at the end of exactly 1 minute by adding $4 \mathrm{~mL}$ of glacial acetic acid. The magenta colour developed was read at $540 \mathrm{~nm}$ with the aid of a UV spectrophotometer. The control enzyme reaction mixture was done the same way as the samples but without any essential oil. The experiment was conducted in triplicate at each dose level.

\section{RESULTS}

The yield of the essential oils were $0.10 \%, 0.11 \%$ and $0.13 \%$ for leaf, stem bark and root bark respectively. GC and GC-MS analyses afforded the identification of 27 compounds in the leaf essential oil, 17 in the stem bark and 14 in the root bark (Table 1). The leaf oil composition comprised of $32.3 \%$ monoterpenoid which are $21.0 \%$ monoterpene hydrocarbon and $11.3 \%$ oxygenated monoterpene. The sesquiterpenoid fraction $(39.7 \%)$ was identified as $21.5 \%$ sesquiterpene hydrocarbons and $18.2 \%$ oxygenated sesquiterpenes. Other constituents were characterized as $3.1 \%$ diterpene, $6.9 \%$ fatty acids and $8.4 \%$ simple aliphatic. 
A high percentage of $33.3 \%$ fatty, $n$ hexadecanoic acid was detected in the stem bark essential oil and other principal constituents which were $\alpha$-pinene $(12.2 \%), \beta$ pinene $(8.9 \%)$, limonene $(4.4 \%)$ and $\alpha$ humulene $(4.7 \%)$.

The leaf, stem bark and root bark essential oils had $\mathrm{LC}_{50}$ values of $16.38 \mu \mathrm{g} / \mathrm{mL}$, $43.11 \mu \mathrm{g} / \mathrm{mL}$ and $39.40 \mu \mathrm{g} / \mathrm{mL}$ respectively which indicate that the oils are toxic to brine shrimps (Table 2). The three essential oils (leaf, stem bark and root bark) exhibited promising activity of $\mathrm{IC}_{50} 14.65 \mu \mathrm{g} / \mathrm{mL}, 14.11$ $\mu \mathrm{g} / \mathrm{mL}$ and $11.22 \mu \mathrm{g} / \mathrm{mL}$ respectively against AChE (Table 3).

Table 1: Essential oil constituents of the leaves, stem barks and root barks of Ficus capensis.

\begin{tabular}{|c|c|c|c|c|c|}
\hline $\mathbf{S} / \mathbf{N}$ & Compound & $\mathbf{R I}^{*}$ & Leaf (\%) & $\begin{array}{l}\text { Stem bark } \\
(\%)\end{array}$ & $\begin{array}{l}\text { Root bark } \\
(\%)\end{array}$ \\
\hline 1. & $\alpha$-thujene & 933 & - & 0.2 & 0.7 \\
\hline 2 & $\alpha$-pinene & 941 & 9.3 & 12.2 & 36.7 \\
\hline 3 & camphene & 954 & - & 1.6 & 0.5 \\
\hline 4 & $\beta$-pinene & 981 & 4.5 & 8.9 & 14.9 \\
\hline 5 & $\alpha$-phellandrene & 1007 & - & 0.8 & 1.8 \\
\hline 6 & $p$-cymene & 1021 & - & 1.5 & - \\
\hline 7 & $m$-cymene & 1023 & 2.1 & - & 5.8 \\
\hline 8 & limonene & 1030 & 3.1 & 4.4 & 7.9 \\
\hline 9 & $\gamma$-terpinene & 1058 & 2.0 & 3.7 & 4.1 \\
\hline 10 & terpinolene & 1088 & - & 1.9 & 0.1 \\
\hline 11 & safranal & 1183 & 1.1 & - & - \\
\hline 12 & (Z)-ocimenone & 1222 & 2.8 & - & - \\
\hline 13 & $n$-tridecane & 1300 & 1.9 & - & - \\
\hline 14 & $n$-tetradecane & 1397 & 6.5 & - & - \\
\hline 15 & cyperene & 1403 & - & 1.0 & - \\
\hline 16 & isocaryophyllene & 1406 & 3.4 & 0.5 & - \\
\hline 17 & $\alpha$-ionone & 1408 & 6.4 & - & - \\
\hline 18 & $(E)$ - $\beta$-caryophyllene & 1420 & 1.8 & - & 3.6 \\
\hline 19 & geranylacetone & 1428 & 1.1 & - & - \\
\hline 20 & $(E)$ - $\alpha$-bergamotene & 1433 & - & 1.3 & - \\
\hline 21 & $\alpha$-humulene & 1455 & 6.5 & 4.7 & 3.2 \\
\hline 22 & $\beta$-ionone & 1464 & 1.0 & - & - \\
\hline 23 & germacrene & 1477 & 2.4 & - & - \\
\hline 24 & $\gamma$-humulene & 1485 & 0.7 & - & - \\
\hline 25 & $\delta$-amorphene & 1512 & 1.2 & - & - \\
\hline 26 & $E$-nerolidol & 1544 & 3.1 & - & - \\
\hline 27 & $\begin{array}{l}3 E, 7 E-4,8,12 \text {-trimethyltri } \\
\text { deca-1,3,7,11-tetraene }\end{array}$ & 1561 & 1.3 & - & - \\
\hline 28 & spathulenol & 1566 & 3.7 & - & - \\
\hline 29 & caryophyllene oxide & 1570 & 3.9 & - & - \\
\hline 30 & $\alpha$-cadinol & 1641 & 10.6 & - & - \\
\hline 31 & $n$-tetradecanoic acid & 1736 & - & 2.1 & - \\
\hline 32 & neophytadiene, Isomer I & 1821 & 0.9 & - & 1.2 \\
\hline 33 & pentadecanoic acid & 1831 & - & 4.0 & - \\
\hline 34 & neophytadiene, Isomer II & 1841 & 0.8 & - & - \\
\hline 35 & neophytadiene, Isomer III & 1862 & 1.4 & - & - \\
\hline 36 & $n$-hexadecanoic acid & 1931 & - & 33.3 & 15.5 \\
\hline \multirow[t]{2}{*}{37} & geranyllinalool & 1944 & 6.9 & - & - \\
\hline & TOTAL & & $90.4 \%$ & $82.1 \%$ & $96.0 \%$ \\
\hline
\end{tabular}

$\mathrm{RI}^{*}=$ Retention Index (Adams, 2001) 
Table 2: Brine shrimp toxicity assay of the essential oils.

\begin{tabular}{lccc}
\hline Essential oil & $\begin{array}{c}\mathbf{L C}_{\mathbf{5 0}} \\
(\boldsymbol{\mu g} / \mathbf{m L})\end{array}$ & $\begin{array}{c}\text { Lower } \\
\text { confidence limit }\end{array}$ & $\begin{array}{c}\text { Upper } \\
\text { confidence limit }\end{array}$ \\
\hline F. capensis (leaf) & 16.38 & 9.80 & 25.43 \\
F. capensis (stem bark) & 43.11 & 24.71 & 72.46 \\
F. capensis (root bark) & 39.40 & 18.17 & 72.89 \\
\hline
\end{tabular}

Table 3: Acetyl cholinesterase inhibitory properties of the essential oils.

\begin{tabular}{ll}
\hline Essential oil & $\mathbf{I C}_{\mathbf{5 0}}(\boldsymbol{\mu g} / \mathbf{m L})$ \\
\hline F. capensis (leaf) & 14.65 \\
F. capensis (stem bark) & 14.11 \\
F. capensis (root bark) & 11.22 \\
Huperzine A & 7.23 \\
& \\
\hline
\end{tabular}

\section{DISCUSSION}

The high percentage of $n$ hexadecanoic acid in the sample is significant. Hexadecanoic acid has been found in higher amounts $(69.1 \%)$ in the essential oils of Cestrum diurnum (Bhaltacharjee, 2005). Ekundayo et al. (1991) also detected fatty acids from Psidium guajava, lauric and myristic acids (34\%).

The root bark essential oil comprised of predominantly monoterpenes $(72.5 \%)$. The major components were $\alpha$-pinene $(36.7 \%), \beta$ pinene $(14.9 \%), m$-cymene $(5.8 \%)$, limonene $(7.9 \%)$ and $n$-hexadecanoic acid $(15.5 \%)$. The minor constituents were $\alpha$-thujene $(0.7 \%)$ and camphene (0.5\%). A diterpene, neophytadiene, Isomer I (1.2\%) was also identified in the essential oil. The two sesquiterpenes compounds amounted to $6.8 \%$, consisting of (E)- $\beta$-caryophyllene $(3.6 \%)$ and $\alpha$-humulene $(3.2 \%)$. The result suggests that the root bark essential oil can be classified as the $\alpha$-pinene chemotype. $\alpha$-Pinene has shown biological activities as antioxidant, antiradical and antimicrobial (Gianni et al., 2005). However, five constituents of varying concentrations were common to the three essential oils. These compounds are $\alpha$-pinene (9.3-36.7\%), $\beta$-pinene (4.5-14.9\%), limonene $(3.1-7.9 \%), \quad \gamma$-terpinene $(2.0-4.1 \%)$ and $\alpha$ humulene (3.2-6.5\%).
Thus, analyses of the leaf, stem bark and root bark volatile oils revealed both quantitative and qualitative variations in their composition. There are no literature reports on the essential oil constituents of the part studied.

Toxicity to brine shrimps has been correlated with cytotoxic, pesticidal, antibacterial and anti-tumor properties (McLaughlin et al., 1993).

The activities of the three essential oils compared favourably with the positive control, Huperzine A with $\mathrm{IC}_{50}$ of 7.23 $\mu \mathrm{g} / \mathrm{mL}$. Huperzine A was isolated from Huperzia serrata (Thunb. Ex Murray) (a traditional Chinese medicinal plant used for the treatment of fever and memory improvement (Patocka, 1998; Shu, 1998). Huperzine A also showed a strong reversible and highly selective inhibitory activity against the enzyme acetyl cholinesterase (Tang and Han, 1999). It has been reported (Huperzine A) to show strong inhibition over other commercially available inhibitor (Patocka, 1998; Xiao et al., 2002; Xu, 1999) thus, the choice as a standard in acetyl cholinesterase enzyme assays. The result of this study is an indication that $F$. capensis can be explored in treatment of cases related to memory improvement, for example Alzheimer's disease (AD). 
Furthermore, the observed activities are significant when compared to essential oils from some plants. Dohi et al. (2009) reported the $\mathrm{AChE}$ inhibitory activity of some commercial essential oils, of which Artemisia dracunculus $\mathrm{L}$ showed the most potent inhibitory activity of $58.0 \mu \mathrm{g} / \mathrm{mL}$. The volatile oil from the bark of Peltophorum dasyrachis Kurz ex Baker showed potent inhibitory activity with the $\mathrm{IC}_{50}$ value of $83.2 \mu \mathrm{g} / \mathrm{mL}$ (Fujiwarat et al., 2010).

However, the result of this study is a preliminary attempt and also the first at investigating the AChE inhibitory activity and toxicity of these oils. There is the need to deduce the relationship between the constituents and the observed activities.

\section{ACKNOWLEDGEMENTS}

The authors are grateful to Dr. M. A. Adio for his technical assistance.

\section{REFERENCES}

Adams RP. 2001. Identification of Essential Oils by Ion Trap Mass Spectrometry. Allured Publishing Corporation: Carol Stream, Illinois.

Akinsinde KA, Olukoya DK. 1995. Vibriocidal activities of some local herbs. Journal of Diarrhoeal Diseases Research, 13(2): 127-129.

Baum G. 1971. Determination of acetyl cholinesterase by an organic substrate selective electrode. Analytical Biochemistry, 39: 65-72.

Berg CC. 1989. Classification and distribution of Ficus. Experientia, 45: 605-611.

Bhaltacharjee I, Ghosh A, Chandra G. 2005. Antimicrobial activity of the essential oil of Cestrum diurnum L. (Solanales: Solanaceae). African Journal of Biotechnology, 4: 371-374.

Chiang Y, Chang J, Kuo C, Chang C, Kuo Y. 2005. Cytotoxic triterpenes from the aerial roots of Ficus microcarpa. Phytochemistry, 66: 495-501.

Davies NW. 1960. Gas chromatographic retention indices of monoterpenes and sesquiterpenes on Methyl silicone and
Carbowax 20M Phases. Journal of Chromatography, 503: 1-24.

Dohi S, Terasaki M, Makino M. 2009. Acetyl cholinesterase inhibitory activity and chemical composition of commercial essential oils. Journal of Agricultural and Food Chemistry, 57(10): 4313-4318.

Ekundayo O, Ajani F, Seppanen-Laakso T, Laakso I. 1991. Volatile constituents of Psidium guajava L (Guava) fruits. Flavour and Fragrance Journal, 6: 233236.

Finney DJ. 1971. Probit Analysis ( $3^{\text {rd }}$ edn). Cambridge University Press: London.

Fujiwarat M, Yagi N, Miyazawa M. 2010. Acetyl cholinesterase inhibitory Activity of Volatile oils from Peltophorum dasyrachis Kurz ex Bakor (Yellow Batai) and Bisabolane-type sesquiterpenoids. Journal of Agricultural and Food Chemistry, 58(5): 2824-2829.

Gianni S, Silvia M, Mariavittoria M, Martina S, Stefano M, Matteo R, Renato B .2005. Comparative evaluation of 11 essential oils of different origin as functional antioxidants, antiradicals and antimicrobials in foods. Food Chemistry, 91(4): 621-632.

Grison-Pige L, Hossaert-Mc Key M, Greeff JM, Bessiere JM. 2002. Fig volatile compounds-a first comparative study. Phytochemistry, 61: 61-71.

Irvine FR. 1961. Woody Plants of Ghana with Special References to Their Uses. Oxford University Press: London; 398-450.

McLaughlin JL, Chang CJ, Smith DL. 1993. Simple bench-top bioassay (brine shrimp and potato discs) for the discovery of plant antitumour compounds. In Human Medical Agent from Plants. Kinghorn, A.D and Balandrin, M.F (Eds), ASC Symposium, Washington D.C. American Chemical Society, 534: 112-137.

Muregi FW, Chabra SC, Njagi ENM, Lang'atThoruwa CC, Njue WM, Orago ASS, Omar SA, Ndieje, IO. 2003. In-vitro antiplasmodial activity of some plants used in Kisii, Kenya against malaria and their chloroquine potential effects. 
Journal of Ethnopharmacology, 84: 235239.

Oladosu IA, Zubair F, Olawore NA, Shaiq M. 2009. Anticandidal activity of volatile compounds from the root bark of Ficus exasperata Vahl-Holl (Moraceae). Journal of Essential Oil Bearing Plant, 12(5): 562-568.

Patocka J. 1998. Huperzine A, an interesting anticholinesterase compound form the Chinese herbal medicine. Acta Medicine, 41: 155-157.

Proffit N, Johnson SD. 2009. Specificity of the signal emitted by figs to attract their pollinating wasps: Comparison of volatile organic compounds emitted by receptive syconia of Ficus sur and Ficus sycomorus in Southern Africa. South Africa Journal of Botany, 75: 771-777.

Sharaf M, Abu-Gabal NS, El-Ansari MA. 2000. Exudate flavonoids from Ficus altissima. Biochemical Systematics and Ecology, 28: 291-293.

Shu YZ. 1998. Recent natural products based drug development: a pharmaceutical industry perspective. Journal of Natural Product, 61: 1053-1071.
Sonibare MA, Jayeola AA, Egunyomi A. 2005. Chemotaxonomic significance of leaf alkanes in species of Ficus (Moraceae). Biochemical Systematics and Ecology, 33: 79-86.

Sonibare MA, Ogunwande IA, Walker TM, Setzer WN, Soladoye MO, Essien EE. 2006. Volatile Constituents of Ficus exasperata leaves. Natural Products Communication, 1(9): 763-765.

Tang XC, Han YF. 1999. Pharmacological profile of huperzine A, a novel acetyl cholinesterase inhibitor from Chinese herb. CNS Drug Review, 5: 281-300.

Xiao XQ, Zhang HY, Tang XC. 2002. Huperzine A attenuates amyloid betapeptide fragment 25-35 induced apotosis in rat cortical neurons via inhibiting reactive oxygen species formation and caspasc-3 activation. Journal of Neuroscience Research, 67: 30-36.

Xu S, Cai ZY, Qu ZW. 1999. Huperzine-A in capsules and tablets for treating patients with Alzheimer disease. Acta Pharmacological Sinica, 20(6): 486-490. 